\title{
The Global Governance of Paid Domestic Work: Comparing the Impact of ILO Convention No. I 89 in Ecuador and India
}

Critical Sociology $1-15$

(C) The Author(s) 2018 Reprints and permissions: sagepub.co.uk/journalsPermissions.nav DOI: $10.1 \mid 77 / 0896920517751590$ journals.sagepub.com/home/crs

(SAGE

\section{Sabrina Marchetti}

Ca' Foscari University. Italy

\begin{abstract}
This article looks at the gradual development of a 'global governance of paid domestic work' by assessing the impact of the ILO Convention n. 189 on campaigns for domestic workers' rights in different countries. Here I compare the case of Ecuador and India as two contrasting examples of the ways in which state and non-state organizations have positioned themselves around the issue, revealing how the context-dependent character of domestic workers' rights can ultimately condition the mobilisation of different actors in each context. On the basis of the theory of 'strategic fields of action', I also define the promulgation of CI89 as an 'exogenous change' that has differing impacts on the relevant social actors in two countries. As I will show, these national differences give shape to a very different modality in campaigns for domestic workers' rights, resulting in different roles, purposes and scope of action for key social actors.
\end{abstract}

\section{Keywords}

Ecuador, India, ILO, domestic work, CI89I, social movements, labour rights

\section{Introduction}

In Geneva on 16 June 2011, amidst the clapping and singing of dozens of domestic workers gathered from all over the world, the International Labour Organisation (ILO) passed 'Convention No. 189 concerning decent work for domestic workers' and the relative Recommendation No. 201. This is a striking achievement in comparison to the traditional lack of rights for a category of labourers who, in different social contexts, usually belong to the most impoverished and socially stigmatised groups (poor women and children, undocumented migrants, ethnic minorities, etc.). In several countries, domestic work is not recognised 'as work' and is therefore excluded from labour protections. Domestic workers are often deprived of monetized salaries and compensated with

\section{Corresponding author:}

Sabrina Marchetti, Department of Philosophy and Cultural Heritage, Ca' Foscari University, Dorsoduro 3484/D, 30I23

Venice, Italy.

Email: sabrina.marchetti@unive.it 
only food and shelter. Also, in countries where domestic work is regulated through labour laws, the provisions differ significantly from those in place for other jobs, having lower remunerations and less social protection. ${ }^{1}$

However, in recent years, there has been a gradual development of what I call the 'global governance of paid domestic work': a multi-layered and highly heterogeneous framework for the improvement of domestic workers' rights, due to the interplay between different types of global and local actors. In the process, the status of paid domestic workers - their poor conditions and the discrimination they face in different parts of the world - has come to be seen as a 'global problem' whose governance is a challenge that exceeds national borders. In fact, on the institutional side, not only the ILO, but also United Nations (UN) Women, the International Organisation for Migration, the Global Forum on Migration and Development, the European Fundamental Rights Agency, the UN Commission on the Status of Women, and several international trade unions have undertaken specific actions to promote domestic workers' rights in recent years. At the same time, the founding of the International Domestic Workers Federation (IDWF) in Montevideo in 2012 revealed the global expansion of this workers' movement built upon new connections between existing national and regional organisations composed (exclusively) of domestic workers.

In this scenario, I consider the impact of C189 on campaigns for domestic workers' rights waged in different countries. In fact, when one gets closer to the specificities of each country case, the behaviour of social movements, states and international organizations in relation to this issue shows important differences. In this article, I discuss two contrasting ways in which state and nonstate organizations have positioned themselves around the issue, revealing how the contextdependent character of domestic workers' rights can ultimately condition the capacity of C189 to mobilise actors in each context. I utilize the theory of 'strategic fields of action' (Fligstein and McAdam, 2012) to evaluate how the promulgation of $\mathrm{C} 189$ operates as an 'exogenous change' that has differing impacts on the relevant social actors in two countries. By examining each national context through this theoretical lens, I raise key questions such as: how are different local actors reacting to C189 as a 'global governance' measure for domestic workers' rights? What role does the state play in this process? How do such processes relate to wider political and social transformations taking place at the national and regional levels?

To answer these questions, I consider the cases of India and Ecuador, which reflect contrasting examples of how local (state and non-state) actors have taken up C189 as an opportunity to mobilise for domestic workers' rights. In fact, Ecuador and India show two opposite attitudes by the state: the Ecuadorian government actively promotes domestic workers' rights within its broader socio-economic reforms, whilst the Indian government is reluctant to put the question on its political agenda, despite pressure to do so by civil society groups. As I will show, these national differences give shape to a very different modality in campaigns for domestic workers' rights, resulting in different roles, purposes and scope of action for key social actors.

As I will further argue, the differences between India and Ecuador reflect the differences in attitude between their geographical regions: the case of Ecuador mirrors the tendency, at least in the decade before the fieldwork (2014), in the Caribbean and Latin American region (especially in countries with leftist governments like Brazil, Bolivia, Ecuador and Venezuela), to improve the conditions of poor and vulnerable social groups, including women in domestic work (IDWF, 2013b). There seems to be an emulation effect there, with Latin American and Caribbean governments joining the ratification process one after another. Today the region has the highest concentration of ratifications, with 13 signatories at the time of writing (see Table 1). ${ }^{2}$ The case of India is instead contextualised in a region where, in comparison to Latin America, fewer reforms have been adopted to improve the human rights of women and 
Table I. Map of actors and their roles, India and Ecuador (2014).

\begin{tabular}{|c|c|c|}
\hline & INDIA & ECUADOR \\
\hline Exogenous change & $\begin{array}{l}\text { International Labour } \\
\text { Organisation (ILO) } \\
\text { Convention No. } 189 \\
\text { concerning decent work } \\
\text { for domestic workers } \\
\text { (CI89) }\end{array}$ & $\mathrm{Cl} 89$ \\
\hline Strategic field of action & $\begin{array}{l}\text { Human rights for } \\
\text { domestic workers }\end{array}$ & $\begin{array}{l}\text { Equal labour rights for domestic } \\
\text { workers }\end{array}$ \\
\hline $\begin{array}{l}\text { Actors in the field beyond domestic } \\
\text { workers' groups }\end{array}$ & $\begin{array}{l}\text { Pro-equality } \\
\text { organisations (e.g. } \\
\text { Christian missions, } \\
\text { women's groups, } \\
\text { campaigns for Dalit and } \\
\text { 'tribal' people's rights } \\
\text { and informal workers) }\end{array}$ & $\begin{array}{l}\text { Ecuadorian state and } \\
\text { international NGOs (e.g. } \\
\text { CARE and Fonds voor } \\
\text { Ontwikkelingssamenwerking } \\
\text { [FOS-Socialist Solidarity]) }\end{array}$ \\
\hline Relevant actors outside the field & None & $\begin{array}{l}\text { Indigenous and feminist } \\
\text { movements; the traditional } \\
\text { workers' movement }\end{array}$ \\
\hline Incumbent actor in the field & ILO, some Indian states & Ecuadorian state \\
\hline Internal opponent in the same field & Indian state & None \\
\hline $\begin{array}{l}\text { Relationship with the International } \\
\text { Domestic Workers Federation (IDWF) }\end{array}$ & Strong & Weak \\
\hline Regional context & $\begin{array}{l}\text { Civil society: In other } \\
\text { Asian countries, } \\
\text { domestic workers are } \\
\text { increasingly vocal but } \\
\text { still too weak as partners } \\
\text { State: Only the } \\
\text { Philippines ratified CI89 }\end{array}$ & $\begin{array}{l}\text { Civil society: A long tradition } \\
\text { of mobilisation for domestic } \\
\text { workers' rights (e.g. } \\
\text { CONLACTRAHO) } \\
\text { State: Other Latin American } \\
\text { countries have ratified CI89 } \\
\text { (including Argentina, Bolivia, } \\
\text { Chile, Colombia, Costa Rica, } \\
\text { Dominican Republic, Guyana, } \\
\text { Jamaica, Nicaragua, Panama, } \\
\text { Paraguay and Uruguay) }\end{array}$ \\
\hline
\end{tabular}

migrants in general, which has a negative impact on domestic workers' rights in India, Indonesia, Taiwan, Hong Kong, Japan, etc. (IDWF, 2013a). In all of Asia, only the Philippines have ratified $\mathrm{C} 189$ so far.

In the sections that follow, I draw upon this fieldwork in 2014 to develop a comparison of the impact of $\mathrm{C} 189$ in the Ecuadorian and the Indian case. ${ }^{3}$ After introducing the theoretical background and general context of domestic workers' mobilisation, I present my analysis of the data in three parts. First, I describe the conditions of domestic workers, the historical background and recent developments by highlighting the impact of gender-, race-, and citizenship-based inequalities. Second, I examine the question of domestic workers' rights in each context, asking how they are differently framed by stakeholders and how they seem to be generally perceived by society at large. Finally, I illustrate how a 'strategic action fields' approach can apply to the campaign for C189 in each country and the behaviour of state and non-state actors, with the convention being the exogenous factor in this arena. The chapter closes by summarising the comparison between the two country cases and offering concluding remarks. 


\section{Domestic Workers Mobilising for Their Rights at the Global Level}

There are an estimated 52.6 million men and women in paid domestic work around the world today. Amongst them, 43 million are women and 7 million are children (ILO, 2013). This labour sector is particularly important in developing regions: 1 in 4 female wage workers are domestic workers in Latin America and the Caribbean, and almost 1 in 3 in the Middle East. In India, there are about 4 million domestic workers. Some countries are affected by this phenomenon due to the fact that their female population leaves to take up domestic work abroad, as is especially the case in the Asian-Pacific countries, Eastern Europe and South America. The situation of these workers (and of the people they work for) has been greatly influenced by transformations induced by globalisation at different levels (Parreñas, 2005; Schuerkens, 2010). Depending on their specific context, domestic workers might be differently affected by the intensification of international migration, the reorganisation of social classes, the urbanisation of rural and indigenous populations, and changes in gender norms, lifestyles, household organisation and welfare regimes.

However, when engaging in a global approach to paid domestic work, it is important to avoid homogenising domestic workers' realities and to emphasise how, despite the global nature of domestic work, it has different characteristics in each national and regional context. For instance, whilst in Europe and North America it mainly concerns the employment of international migrants by households with children or the elderly (Anderson and Shutes, 2014; Lutz, 2011), in South Africa and other formerly colonised countries it is strongly rooted in the legacy of racial apartheid (Ally, 2011; Cock, 1989). In South America, domestic work is mainly a job for racialised, indigenous and rural populations (Vega Solìs and Gutierrez Rodriguez, 2014), whilst in India it shows the legacy of caste-based differences (Palriwala and Neetha, 2010; Ray and Qayum, 2009). In fact, there is a difference from country to country in the social groups that traditionally perform paid domestic work: migrants, low-caste people, or black and indigenous women, depending on the context. These local specificities are crucial since different socio-cultural contexts will differently shape the social position of domestic workers, and the possibility for transformation, as the cases of India and Ecuador demonstrate.

In some national and regional contexts, domestic workers organising themselves is not a new phenomenon (Piper, 2005). This is especially the case for countries that already have an ad hoc law regarding paid domestic work, such as in several European countries and in South Africa, Brazil and the USA. The labour rights campaigns of domestic worker organisations at the national and regional levels have been the object of several scholarly studies, covering, for example, the USA (Boris and Nadasen, 2008), Italy (Andall, 2000; Sarti, 2010), Latin America (Blofield, 2012), Hong Kong (Constable, 2009) and South Africa (Ally, 2011; Fish, 2006). In Europe, Helen Schwenken (2003) has studied the network called Respect, which in the early 2000s mobilised domestic workers, especially undocumented migrants, from several EU countries. Yet most of the scholarship on domestic workers' organising has focused on the local level; there are few studies of the International Network of Domestic Workers (IDWN) or accounts of the movement as a 'global' phenomenon.

A growing stream of literature is dedicated to the possible advancements brought by $\mathrm{C} 189$, from the legal point of view. ${ }^{4}$ These studies illustrate how the issue of domestic work is not new to ILO's agenda; already in 1948 it had passed a resolution demanding minimum standards for this sector (see Boris and Fish, 2014; Schwenken et al., 2011). However, attention to domestic workers gradually faded away. One reason could be that in the post-war period people commonly believed that the increasing modernisation of domestic life, with the use of technology and more efficient systems to organise the household, would soon make it possible to eliminate the traditional figure of paid domestic workers, seen as a legacy of pre-modern and exploitative times (see Coser, 1973). 
Thus, there was no need for political intervention. It was only in the 1990s, when ILO started its general campaign for the promotion of 'decent work' in flexible and non-standard jobs, that the issue of paid domestic workers re-emerged. In fact, an important historical precondition for the later approval of C189 was the passing in 1996 of ILO Convention No. 177, which set labour standards for home work (Prügl, 1999). It is unlikely that a convention for domestic workers would have been possible without ILO's previous emphasis on a gendered approach to non-standard jobs.

C189 further testifies to ILO's enhanced role as a 'global governance' actor in dismantling the discrimination against feminised occupations, but also in contrasting the ethnicised, religious, class-based assumptions that have contextualised the social status of domestic workers and lowskilled informal workers around the world. The next section examines how this type of intervention has been taken up at the national level in Ecuador and India.

\section{Describing the Context: Paid Domestic Work in Ecuador and India}

\section{Ecuador: Speedy Progress towards Equality?}

Paid domestic work in Ecuador generally consists of two forms of employment: live-in (puertas adentro) and live-out (puertas afuera). The live-in form was popular until the 1990s and girls employed in this way were excluded from further educational or working opportunities, which ultimately reinforced their gendered and ethnicised segregation (see Hollenstein, 2009). However, recent improvements in the Ecuadorian economy, an increase in literacy levels and a reduction in poverty have certainly had a positive impact on these social groups (Vázquez and Saltos, 2013). In a survey conducted by Karla Moncayo Roldán (2015), only 28\% of participants still work live-in, whilst the majority work on an hourly basis earning between $\$ 200$ and $\$ 280$ per month. Amongst survey participants, $25 \%$ report having started working before 15 years of age, which is prohibited by current laws.

On 14 April 2015 the Ecuadorian state adopted its first law on paid domestic labour. This exceptional achievement is the result of a long process that started in 2006 and has gradually seen improvements in the legislation concerning this category of workers. As Karla Moncayo Roldán (2015) illustrates, the first step was the inclusion of domestic workers in the minimum wage decree, which, following a series of gradual annual increases, raised the minimum wage for a domestic worker from $\$ 50$ a month in 2004 to $\$ 340$ in 2014 . Actual equality between the minimum wage for a domestic worker and for other workers with comparable jobs in the private sector was achieved in 2010 (Moncayo Roldán, 2015). This means Ecuador has finally joined Chile and Brazil in granting full-time domestic workers a salary on a par with the minimum basic income (salario minimo vital). ${ }^{5}$ This evolution in the contractual conditions for domestic workers was prompted by the ratification of C189 in December 2013, which demanded that the government adjust the national laws accordingly. With this, Ecuador was the fifth Latin American country to ratify C189 (after Bolivia, Guyana, Nicaragua, Uruguay and Paraguay). ${ }^{6}$

The improvement in the conditions of paid domestic work in Ecuador was the result of profound historical transformations taking place in this sector. In her thesis, Moncayo Roldán (2015) recounts the history of domestic workers in Ecuador, paying specific attention to their working conditions and their legal protections. This history starts in colonial times, when today's Ecuador was ruled by Spain and domestic workers were enslaved people from indigenous groups or from the Africans traded to South America to work on plantations. The legacy of slavery was very strong up until the 1970s, which were crucial years in Ecuadorian history; this decade saw the abolishment of indentured labour and servant-hood, an increase in the industrialisation of the country and periodic 
economic recessions (Vázquez and Saltos, 2013). The effects of these transformations were, amongst other things, strong internal migrations towards the main cities (Quito, Guayaquil and Cuenca) and, later on, migrations abroad.

Migration, in particular, had strong repercussions for the organisation of paid domestic work in Ecuador. Domestic workers were usually young girls from families who had migrated out of impoverished regions, like the mountains or coastal areas, where the plantation economy was in crisis. These young women thus belonged to poor and ethnicised groups, such as Afro-Ecuadorians or indigenous people living on the outskirts of cities. In Quito, for example, most domestic workers had indigenous Andean backgrounds, whilst Guayaquil counted more domestic workers of AfroEcuadorian origin. Today, Peruvians and Colombians - the main foreign nationalities in Ecuador - are increasingly taking up these jobs, especially under irregular employment conditions. Ecuadorian women, on the other hand, are often employed as domestic workers in their places of emigration, such as Italy and Spain (Herrera, 2013).

Despite the recent legislative improvements, it is not yet clear how much they improve the reality of Ecuadorian domestic workers. Data from the Ecuadorian national statistics office estimates the proportion of domestic workers who are employed without a regular contract at around $80 \%$. In 2010, the Ministry of Labour counted a total of 173,000 domestic workers in the country, of which only 43,000 were formally employed. In 2012, the newspaper El Universo reported as many as 224,000 domestic workers, whilst official data still refer to less than 50,000 people with a contract. In the interviews that I carried out, the informants were concerned that the rise in salaries and social security contributions might lead employers to fire their workers, or cancel their contracts.

\section{India: The Intertwining of 'New' and 'Old' Forms of Domestic Work}

India is, together with Brazil, one of the two largest employers of domestic workers in the world (the ILO estimates that up to 9 million people work in this sector). Many Indian households hire either men or women, sometimes children, for everyday housework, often paying them in-kind instead of with cash. Indian domestic workers migrate to the Gulf states, but increasing numbers of migrant women also migrate to Indian cities such as Delhi; smaller numbers of Bangladeshi and Nepalese women also migrate to Indian cities. ${ }^{7}$

The Indian context shows an interesting combination of 'new' and 'old' forms of paid domestic work. The old form of domestic work relies on a traditional vision of social hierarchies based on the caste system, in which religious practices concerning domestic tasks play a fundamental role (Ray and Qayum, 2009; Sharma, 2014). For this reason, historically speaking, domestic workers consist of men and women from lower castes who work in higher-caste households in exchange for social protection, monetary compensation or food and shelter.

In this old form of domestic work, each task (like sweeping the floor, washing the toilets, doing the laundry, cooking or dishwashing, collecting the garbage, etc.) is performed by a different person depending on his or her caste position. People from low castes also have internal hierarchies and refuse to perform tasks they consider too impure for themselves. This means that in the same house different people would come and go several times a day to do their assigned tasks at the right moment, and that everyday these workers would come and go from all the houses where they work. This typology of households would normally employ a cook (often a man), a person for cleaning toilets and/or collecting the garbage, someone for general cleaning and washing, and also sometimes a driver or someone to do errands and go for groceries. In this traditional organisation of domestic work, benevolent employers offer social protection to their most loyal domestic workers for their entire lives, even supporting them during old age, or when they fall sick. Some employers may pay the education or health expenses of their workers' children. For this reason, the 
employment of domestic workers is explained by many as a form of welfare that compensates for the absence of state support for the large population of poor people in the country. The downside is that it reinforces the personal dependency of the poor on wealthier households.

What I call the 'new' form of paid domestic work relates instead to the increasing phenomenon of employing young women who arrive in the city from rural areas (Mehrotra, 2010; Palriwala and Neetha, 2010). In New Delhi, these internal migrants are usually from neighbouring regions like Punjab, Bihar, Uttar Pradesh, Rajasthan, Haryana, Orissa or Andhra Pradesh. Amongst them are also people from isolated areas, who are often referred to in ethnicising terms as 'tribal' people. Once in Delhi, these internal migrants settle in the slums surrounding the city, from which they travel every day, sometimes for hours (see Sharma, 2014), in order to go to work as rickshaw drivers, street vendors or, in the case of women, as domestic workers. Moreover, because employers want to contain costs and make hiring migrant girls easier, recruitment agencies are flourishing in large Indian cities like Delhi; cases of abuse and trafficking of these young girls are also rising. ${ }^{8}$

Although there are legal frameworks protecting these workers and preventing possible abuses, it is important to note the significant level of state variation in India. In the southern states of Kerala, Tamil Nadu or Karnataka, for instance, domestic workers are entitled to labour contracts the same way all other workers are. In the area of Delhi, however, no labour contract exists for this category, and, thus, no requirements concerning working hours, payments, abuse, etc., apply to them. The last proposal for a national bill on domestic workers' labour rights dates back to 2008, when the National Platform for Domestic Workers drew up a proposal for the then-Sonia Gandhi Congress Party government. No news has come yet from the Narendra Modi government on this issue.

\section{Framing the Question of Domestic Workers' Rights in Ecuador and India}

\section{Domestic Workers' Rights and the Revolucion Ciudadana in Ecuador}

When considering the impact of C189 on Ecuador, one must acknowledge that Rafael Correa's government has been leading the changes. Correa has paid particular attention to establishing a fruitful collaboration with domestic workers: he has invited them to personal meetings (he has already had two private lunches with representatives from domestic workers' groups in the presidential palace) and he has involved them in the necessary consultations to begin legal reforms. The Ministry of Labour has also shown a particular commitment to the regularisation of paid domestic work, organising numerous capacity-building initiatives for domestic workers (15,000 women had received this training by 2013) and inaugurating a massive sensitisation campaign directed at (or rather against) employers. Information points have been organised in city squares, and random inspections have been carried out in wealthy neighbourhoods of cities like Quito. Finally, in official communications the government has adopted strong equality-based language that emphasises the social value of domestic workers, for example calling them trabajadoras remuneradas del hogar instead of using the traditional denomination domesticas, which is considered derogatory today.

The government intervention in this sector is part of the wider political and social change that Correa is promoting under the principles of 'buen vivir' (good life) and the 'revolución ciudadana' (civic revolution), as they are explained in the new constitution adopted in 2008. This project does not limit itself to the national context, but it is also strongly motivated by regional interests, with the aim of strengthening political and economic partnerships with other Latin American countries (Vázquez and Saltos, 2013). Being able to find common cause with working-class groups is essential to this project. 
However, despite the above-mentioned improvements in the lives of the Ecuadorian population, the government is still fiercely criticised by various political and labour organisations, in particular those that relate to the indigenous movement, the communist party, trade unions and the feminist movement (Vázquez and Saltos, 2013). These groups represent the historical backbone of Ecuadorian civil society and, after an initial hesitation, they are all currently opposing the government for its policy in the fields of economic and labour reforms, the environment, freedom of expression and reproductive rights. It is important to emphasize that domestic workers were probably one of the few (numerically large) categories of working-class people who, not being already organised or politically positioned, the government could smoothly incorporate into its network of alliances (Cangianti, 2014). In other words, Ecuador offers the example of a country where the C189 campaign was not seen by local actors (the government especially) as superimposed by ILO and other international organisations, but it was actually quickly taken up and incorporated into the ideals of equality and social progress that, notwithstanding all limitations, the current government fiercely proclaims as part of the national interest.

\section{Domestic Workers' Rights as Cultural Issue in India}

In contrast to Quito, violence and abuse suffered by domestic workers was a recurrent topic in the news during my stay in New Delhi. The Indian public is frequently saddened by news of the tortures and killings of domestic workers. The period of my stay was no exception, and reactions to such news often provided the framework for understanding key informants' views on domestic workers' labour rights. The human rights of domestic workers were seen as constantly under threat and as a reason for great concern. Although, as I have mentioned before, most of these abuses are connected to new forms of domestic work, the interviewees also tended to explain them as an inheritance of the traditional Indian caste culture, for instance by saying, 'Feudalism is alive in India'. Others more explicitly associated the bad treatment of domestic workers with the Hindu religion and with a large stratum of the population that does not value equality, independent of their education or class background. In other words, violence against domestic workers (people from the lowest caste position) was implicitly legitimated in traditional circles.

Moreover, interviewees framed these contrasting views on domestic workers' social status as a matter of a division within Indian identity, as 'one India against the other', emphasising the strong identity discourse which surrounds the issue of paid domestic work. Along these lines, advocates for domestic workers' rights are portrayed as belonging to social groups that have historically promoted equality and a human rights-based vision in India. These can be associated with long-standing traditions within Indian civil society, such as the Gandhian movement, the feminist movement, the Dalit rights movement, or groups that have been more influenced by Christianity or socialist political ideals. Some interviewees referred to the fact that in regions such as Kerala, Tamil Nadu and Karnataka, which have different religious and political traditions, domestic workers are already entitled to labour rights.

The variety of political traditions that defend a pro-human rights approach is the same that promoted the National Platform for Domestic Workers, the organisation that elaborated the last bill proposal for domestic workers' rights. This organisation gathers in Delhi every six months. Leading members come from the women's rights movement, from Christian organizations, and from trade unions. Several members are from southern regions of India, where domestic workers have already achieved equal labour rights. This organisation was fundamental in campaigning for the Indian government to vote in favour of C189 in Geneva, on 16 June 2011. Yet no promises have been made for a ratification of the convention at the national level. These groups therefore keep active by organising meetings and demonstrations. 


\section{89 as Exogenous Change: Different 'Fields' and Different Actors in Ecuador and India}

To better understand the top-down effects of global governance measures on local realities, I utilize the theory of fields developed by Neil Fligstein and Doug McAdam (2012), which outlines a comprehensive system of guiding principles to interpret collective actors' behaviour and reciprocal actions. According to Fligstein and McAdam, the concept of 'fields' describes a meso-level dimension in which individual and collective actors interact with each other in light of shared yet not forcefully consensual purposes. In my analysis of the global governance of domestic work, I find particularly useful the idea that actors who belong to the same 'strategic field of action' share a common understanding of what threats they may face and what opportunities they may have, which influences the way they frame their actions, goals and results.

To apply this theory, it is essential to identify the exact contours of a field: that is, who is in and who is out based on the general focus of their actions, rather than a singular target. Actors in the same field do not need to have the same position or the same specific intentions; they can be in opposition. Some actors (also called 'incumbent actors') may impose their views on others, and still others may remain marginal, sometimes voicing their dissent or proposing alternative views (also called 'challengers'). Since fields alternate between moments of internal stability and moments of crisis and change, the position of actors within the field - and the relationship between them - may change. Fields can be animated by coercion, competition or cooperation. They can be based on hierarchy or coalition, depending on transformations in the power held by each actor. Any impression of stability is only apparent, since any field is actually under the constant presence of a pressure, a contention or a threat/opportunity, and this is what keeps together the actors in the field. Thus, for Fligstein and McAdam, 'fields are constructed on a situational basis' (2012: 26). There are no objective criteria determining whether an actor is included in the field or not, because this depends on the subjective 'standing' of the actor in it, and the issues which are subjectively at stake in each moment.

Particularly determinant is what Fligstein and McAdam call 'episodes of contention', which consist of periods in which new forms of interaction between actors emerge. When a specific actor starts shaping new modes of interaction with others, they influence perception about what constitutes a threat or an opportunity - or what the authors describe as 'emergent mobilisation'. This is usually provoked by an 'exogenous change' and can also lead to the formation of a new field that occupies a previously unorganised social space. I will show how C189 can be seen as the exogenous change that, both in Ecuador and in India, triggered the formation of a new emergent mobilisation for the improvement of domestic workers' rights. What changes, as I will show, is the role of states in relations to this new field.

Following Fligstein and McAdam, I show that states can indeed have different functions in this respect. They can facilitate the formation of a field by, for example, actively backing particular groups (e.g. sponsorship) or, more passively, by consolidating conditions of the stable non-state actors. A new law, a new judicial ruling, etc., can create an opportunity for strategic action by established or emergent collective actors. Otherwise, states can have a more passive role, as when organized groups go to state actors and lobby for public interventions towards their interests. At the opposite extreme, states can play the role of the opponent, as described above.

Through the lens of strategic fields of action, I examine whether C189 is an exogenous change that created a new field, or if it created conditions for emergent mobilisations within fields that existed already. This calls for a better understanding of what has been the role of different state and non-state actors in relation to wider political and social transformations in national and regional perspectives. In the following sections, I show how India and Ecuador demonstrate different possible processes and outcomes of $\mathrm{C} 189$ as an example of top-down exogenous change. 


\section{India: Human Rights First}

As I have illustrated, the first step for a 'strategic field' analysis is to identify the contours of the field of interaction between the relevant actors. I am arguing that, in India, this space of interaction can be defined as 'the improvement of the human rights of domestic workers', thus going beyond labour rights to encompass living conditions in general. This represents a particularly broad strategic field of action in which the question of domestic workers' rights is framed as a general issue of equality and human rights. The advantage of having such a broad agenda for Indian domestic workers' organisations is the capacity to mobilise high numbers of people and institutions. This is testified to by the large participation in protests and meetings that the workers have organised, such as the meeting that I attended in January 2014 in Delhi, or the rally with more than 4000 domestic workers that they convened the previous summer.

In this large strategic field, one first finds all the main international actors, such as the ILO, other UN institutions, and IDWF. At the same time, local actors are also very active in the field, such as the anti-trafficking organisation Shakti Vahini, and domestic workers' support groups based in Christian missions, such as Adivasi Jeevan Vikas Sanstha (AJVS) in New Delhi and the National Domestic Workers Movement. All these local groups are members of the National Platform for Domestic Workers that I described in the prior section (see also Table 1).

It is worth noticing, however, that amongst international actors there are no other domestic workers' organisations based in Asia. This is probably due to the fact that no country in Asia (besides the Philippines) has so far ratified C189. In fact, although the Asian context is very dynamic at the moment, with grassroots organisations becoming very vocal in Hong Kong, South Korea, Indonesia and Thailand, these regional actors are still too weak to be solid allies for each other at the local or national level. Therefore, each of them prefers to emphasise their relationship with global actors (like the IDWF) or partner organisations from Europe, South America or elsewhere.

Given this setting, what can be said to have been the impact of C189 in India? I would suggest that $\mathrm{C} 189$ was mainly framed as an opportunity for the Indian domestic workers' movement to achieve at the international level the legitimation that it still largely lacks in its own country. In this sense, as summarised in Table 1, C189 has been used by Indian domestic workers (and their advocates) to validate the campaign that they have been conducting at the local level for many years, and to break out of their isolation at the regional level.

In India the ILO had the role of the incumbent actor in this field. C189 thus constituted an exogenous change that provoked a new emergent mobilisation in the Indian context, gathering around this campaign all relevant actors that in the past had mobilised for general issues of equality and human rights, and have now included domestic workers' rights in their agendas. The ILO's incumbent role is also testified to by the pervasiveness its 'decency of work' and the 'equality of all work' principles in Indian actors' communication strategies. Along these lines, slogans such as 'domestic work is work' and 'decent work for domestic workers' have been rapidly taken up by all actors involved in the field. In other words, the ILO disseminated those new ideals and policy instruments that were key to the large coalition - the National Platform for Domestic Workers - carrying out a strong lobbying activity, which pushed the Indian government to vote in favour of C189 in Geneva in June 2011.

The national government, however, must be seen as the internal opponent in this field, along with the local governments of those Indian regions where there is no protection for domestic workers. This shows the association between the central government and the conservative ruling class which, despite official proclamations about modernization and overcoming the traditional caste system, is not really keen on disrupting the status quo to confront Indian elites on their anti-equality position. It is indeed more at the general level of discourse for and against equality and human 
rights that, as stated above, the case of domestic workers' rights is a terrain of confrontation in the Indian context.

\section{Ecuador: Labour Right as a Goal}

The setting is quite different in Ecuador, starting from the definition of the field on which all relevant actors converge. I believe that this is fairly narrow and can be defined by 'the equality of labour rights for domestic workers'. The purpose of this field is a concrete achievement of salary increases and a new labour law. In fact, the equality discourse that was often used during the interviews was immediately applied specifically to employment conditions. General ideals of gender equality and anti-racism were translated to the concrete level of reforming domestic work 'as work'.

Of course, the main actors in this field, in Ecuador, are domestic workers' organisations. We also find international organisations, such as UN-Women, the ILO, the Belgian NGO called FOSSocialist Solidarity, CARE from the USA, as well as the Christian Youth Workers (in Ecuador called Juventud Obrera Catolica). They all agree that the reform of domestic work is a worthwhile campaign in the fight against sexism and racism, which are inherent to the traditional forms of paid domestic work, and which are incompatible with the modernisation of the country and the enhancement of equality. At the level of intra-regional alliances, Ecuadorian domestic workers are keen to strengthen their relationship with other Latin American organisations, especially with the umbrella organisation that gathers domestic workers from Latin America and the Caribbean called CONLACTRAHO (Confederación Latinoamericana y del Caribe Trabajadoras del Hogar). Less emphasis is placed on strengthening ties with the IDWF which is seen as more distant and whose role in the Latin America region is nonetheless mediated by CONLACTRAHO.

Nevertheless, there are also groups which are excluded from the interactions in this field. At least until I carried out my fieldwork in the summer of 2014, there had not been significant interactions between domestic workers and the indigenous movement or the traditional Ecuadorian workers' movement. Along the same line, domestic workers' groups and feminist organisations were unable to find common ground for collaboration, despite initial interest on both sides. Any assumed commonality of interests based on ideals of gender equality (e.g. on the recognition of the importance of reproductive work) had been overshadowed by class and ethnicised differences amongst them. Some interviewees from the feminist movement viewed the advancement of labour rights for domestic workers as being in contradiction with better conditions for Ecuadorian women in general. Nevertheless, one cannot say that feminist groups opposed domestic workers campaigns. Rather, they were positioned outside the field, as was the case for indigenous and workers' organisations (see Table 1).

In summary, when looking at C189 as an exogenous change it is important to highlight how, in Ecuador, it was an opportunity that was probably perceived earlier by the government and the international NGOs active there than by the domestic workers themselves. As I have described in an earlier section, Rafael Correa's government was very keen on appropriating the language and the ideals of $\mathrm{C} 189$ in order to promote a national campaign on paid domestic work. In this process, he emphasized the importance of finding institutional allies amongst the international NGOs active in Ecuador, like CARE and FOS-Socialist Solidarity, which had already taken up this campaign in their agendas for many years. Unlike the Indian case, however, support of C189 was not framed as a general question of human rights, but more specifically as the need for a new cultural and economic approach to the role of paid domestic workers in society, considered foremost as a category of vulnerable workers. It is within this framework that the government and NGOs fostered the development of domestic workers' organisations. 


\section{Conclusion}

Despite their differences in cultural, socio-economic and political contexts, India and Ecuador are interesting cases for comparison in order to understand the importance of $\mathrm{C} 189$ as an exogenous change (in Fligstein and McAdam's terms) that can have a different impact on state and non-state actors in different national contexts, especially in the interaction between civil society and the state.

Table 1 summarises the main differences between the repercussions of C189 in the two countries. It shows that the interaction between actors has rallied around two different ideas, in the two contexts: the improvement of the human rights of domestic workers, in India, as opposed to the more specific improvements of their labour conditions, in Ecuador. These two different configurations of the purpose of the campaign correspond to the different types of actors who, along with domestic workers' organisations, support and promote the campaign. Given the very broad frame of the campaign in India, it was difficult to find any relevant actor working on equality and human rights issues who did not subscribe to the campaign for domestic workers' rights. This is not the case in Ecuador, however, where stakeholders from the traditional feminist, indigenous and workers' movements did not join the campaign, seeing it as separate from their own goals.

Importantly, India and Ecuador also show different trends in relation to who occupies the role of incumbent actor, meaning the actor who has promoted new normative and legal advancements in domestic workers' rights. Whereas in Ecuador it was the national government that promoted a new normative framework, this is not the case in India, where legislation exists only at the level of some local states (like Kerala). For the rest of the country the ILO remains the main actor in promoting the legal protection of domestic workers. In India, I argue that the national state could actually be described as an internal opponent inside the field.

The Indian and Ecuadorian governments are very differently positioned, in political terms, in relation to domestic workers' rights. In India the government neglects the issue, despite international pressure; in contrast, Ecuador's government embraces the issue to demonstrate the progressive views of the Revolución Ciudadana. This difference corresponds to similar attitudes of civil society and state actors in other countries from the same geographical areas. In fact, Ecuador is only one of the increasing number of Latin American countries that is ratifying C189, which gives the sense of a shared political agenda at the regional level.

In conclusion, despite all the distinctions, one may say that $\mathrm{C} 189$ represented a positive exogenous change in the two countries. In India, $\mathrm{C} 189$ has given domestic workers' groups the opportunity to organise a large campaign legitimised by international bodies. This was an important advancement in the pro-equality campaigns that Indian civil society groups conducted at the local level for a long time, and gave them an opportunity to break out of their isolation in the Asian context. In Ecuador, C189 brought about the engagement of the government and international NGOs, who have put efforts into incorporating the $\mathrm{C} 189$ principles into their own political views, including building alliances with other regional actors and international organisations.

More generally, the comparison between India and Ecuador bears important considerations that might also be valid for other countries. Assuming that C189 is an exogenous element, imposed on national realities from the outside, it can create quite different dynamics. Ecuador exemplifies countries in which policy changes at the international level are endorsed by the local government that, in turn, promotes the changes in a top-down manner to civil society and other stakeholders. The Correa government's ability to carry out a national agenda and reinforce grassroots domestic workers' organisations has made the new laws and consequent policy measures look like the result of government and civil society working together. This strategy might prevent two scenarios in which transformations are stalled: in the first scenario civil society tries to use the exogenous change of C189 to push for transformation, but the finds reluctance from the government side; in the second scenario governments embrace international reforms but due to a lack of participation from civil society actors they are not effective. The first case is well represented, in this chapter, by the case of India. 


\section{Funding}

This research received no specific grant from any funding agency in the public, commercial, or not-for-profit sectors.

\section{Notes}

1. For a statistical overview of domestic workers' conditions in the world, see International Labour Organisation (2013). See also regional reports from International Domestic Workers Federation (IDWF, 2013a and 2013b).

2. Available (accessed 11 November 2017) at: http://www.ilo.org/dyn/normlex/en/f?p=1000:11300:0::NO: 11300:P11300_INSTRUMENT_ID:2551460

3. The analysis presented in this chapter refers to the outcome of short fieldwork missions that I carried out in New Delhi in January 2014 and in Quito in August 2014, as preparation for a wider project. I collected 10 in-depth and topic-oriented personal interviews in each city that were carried out in appointments of at least one hour, using English (in India) or Spanish (in Ecuador), and recorded to digital files. I also referred to online and printed materials produced by key informants' organisations, and other relevant actors, that I gathered during these missions.

4. The convention has already been a topic of numerous studies; see Albin and Mantovalou (2012), Gallotti and Mertens (2013), Oelz (2014), Rosewarne (2013), Schwenken (2013), Visel (2013) and Du Toit (2011).

5. In Ecuador, this is calculated as the individual income that would allow a family of four people, of whom 1.6 are working, to afford the current basket of consumer goods. For example, in January 2014 this was calculated to be $\$ 628.27$; available (accessed 11 November 2017) at: http://www.ecuadorencifras.gob. ec/wp-content/uploads/downloads/2014/02/Reporte_inflacion_Enero_2014.pdf

6. Other countries in Latin America, however, also have legislation protecting domestic workers, like Brazil, which has had a specific law since the 1970s.

7. The United Nations Research Institute for Social Development (UNRISD) is currently conducting comparative research on the campaigns for domestic workers' rights in India, Indonesia and China. For India, in-depth analysis is made in Gujarat and Karnataka. Preliminary results are available in UNRISD (2015).

8. The key informant from the Indian NGO called Shakti Vahini has personally been responsible for operations rescuing trafficked girls, who are housed in a shelter whilst they wait to return to their areas of origin. The key informants from AJVS and from Nirmala Niketan are also mostly occupied with this new category of workers, supporting them in finding good employers in Delhi and in escaping abusive conditions.

\section{ORCID iD}

Sabrina Marchetti (iD https://orcid.org/0000-0002-5765-9522

\section{References}

Albin E and Mantovalou V (2012) The ILO convention on domestic workers: From the shadows to the light. Industrial Law Journal 41(1): 67-78.

Ally S (2011) From Servants to Workers: South African Domestic Workers and the Democratic State. Ithaca, NY: Cornell University Press.

Andall J (2000) Organizing domestic workers in Italy: The challenge of gender, class and ethnicity. In: Anthias F and Lazardis G (eds) Gender and Migration in Southern Europe: Women on the Move. Oxford: Berg, $145-172$.

Anderson B and Shutes I (2014) Migration and Care labour: Theory, Policy and Politics. Basingstoke: Palgrave Macmillan.

Blofield M (2012) Care Work and Class: Domestic Workers' Struggle for Equal Rights in Latin America. Philadelphia, PA: Pennsylvania University Press.

Boris E and Fish JN (2014) 'Slaves no more': Making global labor standards for domestic workers. Feminist Studies 40(2): 411-443. 
Boris E and Nadasen N (2008) Domestic workers organize! Working USA 11(December): 413-437.

Cangianti L (2014) Revolución ciudadana: modernizzazione e conflitto sociale in Ecuador. Available (accessed 11 November 2017) at: http://www.carmillaonline.com/2014/09/16/revolucion-ciudadanamodernizzazione-conflitto-sociale-in-ecuador/

Cock J (1989) Maids and Madams: Domestic Workers under Apartheid. St Paul, MN: Women's Press.

Constable N (2009) Migrant workers and the many states of protest in Hong Kong. Critical Asian Studies 41(1): 143-164.

Coser LA (1973) Servants: The obsolescence of an occupational role. Social Forces 52(1): 31-40.

Du Toit D (2011) Domestic workers' convention: A breakthrough in human rights. Law, Democracy and Development 15: 4-5.

Fish JN (2006) Engendering democracy: Domestic labour and coalition-building in South Africa. Journal of Southern African Studies 32(1): 107-127.

Fligstein N and McAdam D (2012) A Theory of Fields. Oxford and New York, NY: Oxford University Press.

Gallotti M and Mertens J (2013) Promoting Integration for Migrant Domestic Workers in Europe: A Synthesis of Belgium, France, Italy and Spain. Geneva: International Labour Organisation.

Herrera G (2013) 'Lejos de tus pupilas': familias transnacionales, cuidados y desigualdad social en Ecuador. Quito: FLACSO.

Hollenstein P (2009) La reproducción de la dominación racial: experiencias de una familia indígena en Quito. Quito: Abya-Yala.

IDWF (2013a) Report for the Asia Region 2009-2013. Montevideo: International Network of Domestic Workers.

IDWF (2013b) Report for the Latin American Region 2009-2013. Montevideo: International Network of Domestic Workers.

International Labour Organisation (2013) Domestic Workers Across the World: Global and Regional Statistics and the Extent of Legal Protection. Geneva: International Labour Organisation.

Lutz H (2011) The New Maids: Transnational Women and the Care Economy. London: Zed Books.

Mehrotra ST (2010) A Report on Domestic Workers: Conditions, Rights and Responsibilities. New Delhi: Jagori.

Moncayo Roldán KE (2015) Análisis histórico juridico de la condiciones laborales del trabajador domestic ecuatoriano. PhD Thesis, Pontificia Universidad Católica del Ecuador.

Oelz M (2014) The ILO's domestic workers convention and recommendation: A window of opportunity for social justice. International Labour Review 153(1): 143-172.

Palriwala R and Neetha N (2010) Care arrangements and bargains: Anganwadi and paid domestic workers in India. International Labour Review 149(4): 511-527.

Parreñas R (2005) The international division of reproductive labor: Paid domestic work and globalization. In: Appelbaum RP and Robinson WI (eds) Critical Globalization Studies. Hove: Psychology Press, 237-247.

Piper N (2005) Rights of foreign domestic workers: Emergence of transnational and transregional solidarity? Asian and Pacific Migration Journal 14(1/2): 97-119.

Prügl E (1999) What is a worker? Gender, global restructuring, and the ILO Convention on homework. In: Meyer MK and Prügl E (eds) Gender Politics in Global Governance. Lanham, MD: Rowman \& Littlefield Publishers, 197-209.

Ray R and Qayum S (2009) Cultures of Servitude: Modernity, Domesticity, and Class in India. Redwood City, CA: Stanford University Press.

Rosewarne SC (2013) The ILO's Domestic Worker Convention (C189): Challenging the gendered disadvantage of Asia's foreign domestic workers? Global Labour Journal 4(1): 1-25.

Sarti R (2010) Lavoro Domestico e di Cura: Quali Diritti? Roma: Ediesse.

Schuerkens U (2010) Globalization and Transformations of Social Inequality. Oxford: Taylor \& Francis.

Schwenken H (2003) RESPECT for all: The political self-organization of female migrant domestic workers in the European Union. Refuge: Canada's Journal on Refugees 21(3): 45-52.

Schwenken H (2013) Speedy Latin America, slow Europe? Regional implementation processes of the ILO Convention of Decent Work for Domestic Workers. Paper presented at the UNRISD Conference, 
'Regional Governance of Migration and Socio-Political Rights: Institutions, Actors and Processes', 14-15 January, Geneva, Switzerland.

Schwenken H, Prügl E, Pabon R, et al. (2011) An ILO convention for domestic workers. International Feminist Journal of Politics 13(3): 438-443.

Sharma S (2014) Pollution, household-space and stigma from the perspective of women domestic workers. Paper presented at X International Conference on Labour History, 22-24 March, V.V. Giri National Labour Institute, Noida/New Delhi.

UNRISD (2015) A long history of mobilization: Understanding gender-egalitarian policy change in India. Project Brief No. 9. Geneva: UNRISD.

Vázquez SL and Saltos NG (2013) Ecuador: Su Realidad. Quito: Fundación José Peralta.

Vega Solìs C and Gutierrez Rodriguez E (2014) Nuevas aproximaciones a la organización social del cuidado: Debates latinoamericanos. Iconos 50 (Special issue).

Visel S (2013) Who cares? The ILO Convention 'Decent Work for Domestic Workers'. Transnational Social Review 3(2): 229-243.

\section{Appendix}

\section{List of People Interviewed:}

In Quito, Ecuador:

- a head officer from the Ministry of Labour responsible for domestic workers' issues;

- two feminist activists (in separate appointments) belonging to the umbrella organisation Asamblea Mujeres Populares y Diversas;

- a representative of the domestic workers' organisation Trabajadoras Remuneradas del Hogar (TRH);

- a representative of the Belgian NGO Fonds voor Ontwikkelingssamenwerking (FOSSocialist Solidarity);

- a representative from the local ILO office;

- a representative from the local office of UN Women;

- two academic experts, one from the Pontificia Universidad Católica (PUCE) and the other from FLACSO;

- a representative of the Christian Youth Workers (in Ecuador called Juventud Obrera Catolica).

In New Delhi, India:

- two representatives of different programmes within the ILO office in New Delhi (in separate appointments);

- a representative of the Christian organisation National Domestic Workers Movement;

- representatives of the support group for domestic workers Nirmala Niketan;

- two academic experts from Jawaharlal Nehru University and from Ambedkar University;

- an expert from the independent organisation Society for Labour and Development;

- a researcher from the independent Centre for Women's Development Studies;

- the organisers of the Catholic domestic workers' support group called Adivasi Jeevan Vikas Sanstha (AJVS);

- a representative from the anti-trafficking organisation Shakti Vahini. 